\title{
Chemical composition and antimicrobial activity of essential oil from Pyrethrum pulchrum Ledeb.
}

\author{
Uugangerel Erdenetsogt ${ }^{1}$, Choijamts Gotov ${ }^{1}$, Kerstin Voigt ${ }^{2}$, Stefan Bartram³ ${ }^{3}$. Wilhelm Boland ${ }^{3}$, \\ Enkhmaa Dagvadorj ${ }^{1 *}$
}

${ }^{1}$ School of Bio-Medicine, Mongolian National University of Medical Sciences, Zorig St., Ulaanbaatar 14210, Mongolia

${ }^{2}$ Leibniz Institute for Natural Product Research and Infection Biology, Hans Knöll Institute

(HKI), Adolf-Reichwein Str. 23, Jena 07745, Germany

${ }^{3}$ Max Planck Institute for Chemical Ecology, Hans-Knöll Str. 8, Jena 07745, Germany

*Corresponding author: enkhmaa.d@mnums.edu.mn; ORCID ID:0000-0003-0138-4790

Received: 01 December 2018; revised: 07 January 2019; accepted: 08 January 2019

\begin{abstract}
The chemical composition and antimicrobial activity of the essential oil from the aerial parts of Pyrethrum pulchrum Ledeb. were investigated. Dried plant material was hydro-distillated yielding $0.1 \%$ of essential oil. The oil was analyzed by GC-MS techniques. Fifty-five compounds were identified representing $99.7 \%$ of the total oil composition. Camphor was the predominant compound (33.9\%) followed by linalool $(21.1 \%)$ and $\alpha$-pinene $(9.0 \%)$. The antimicrobial activity of the oil was determined using the disk diffusion method against Gram-positive bacteria (Bacillus subtilis, Staphylococcus aureus and Enterococcus faecalis), Gram-negative bacteria (Pseudomonas aeruginosa and Escherichia coli), Mycobacterium vaccae and fungi (Candida albicans, Sporidiobolus salmonicolor and Penicillum notatum). The essential oil of $P$. pulchrum displays an intermediate activity against selected bacteria.
\end{abstract}

Keywords: Asteraceae, Pyrethrum pulchrum, Tanacetum, essential oil, camphor

\section{INTRODUCTION}

The Asteraceae also known as Compositae or sunflower family, comprises of the largest family of flowering plants with over 1900 genera and ca. 40000 species [1]. The genus Tanacetum Ledeb., formerly Pyrethrum Zinn, is a large, poorly defined classification group in the Asteraceae containing 150-200 species distributed over West Asia and Europe [2, 3]. Many species of this genera have traditionally been used as a spicy additive for food, in cosmetics and as herbal remedies due to their biologically active compounds [4]. Moreover, Tanacetum has been used as medicinal plants for over 2000 years [5] and it is a known remedy for the treatment of many diseases, including women's ailments, psoriasis, toothache, insect bites, rheumatism, asthma, vertigo and migraine prophylaxis $[6,7]$, while Pyrethrum is used for treating various inflammatory disorders, wound, anthrax, bone fractures as well as reducing fever $[8,9]$.

The strong and aromatic odor of the Tanacetum species is mainly due to high concentrations of volatile terpene constituents in their essential oil, especially in their leaves and flowers [10]. Camphor, 1,8-cineole, $\alpha$-thujone, carvone, thymol, trans-sabinyl acetate, borneol, caryophyllene oxide, (E)-myroxide, sabinene, bornyl acetate, isopulegone, artemisia ketone, limonene, and camphene were identified as the main constituents of Tanacetum species essential oils [3,11]. It is well known, this genus is also found to contain sesquiterpene lactones, a large group of molecules with several biological activity [11]. Several studies have shown that essential oils and extracts of the genus Tanacetum exhibit anti-inflammatory, anticancer, antibacterial, antifungal, anthelmintic, insecticidal and antiprotozoal effects [12-14].

According to literature, six species present in Mongolia that belong to two different genera of Tanacetum and Pyrethrum, namely Tanacetum tanacetoides, T. vulgare, Pyrethrum pulchrum, P. lanuginosum, $P$. alatavicum and $P$. changaicum [15]. $P$. pulchrum is

(C) The Author(s). 2018 Open access This article is distributed under the terms of the Creative Commons Attribution 4.0 International License (http://creativecommons.org/licenses/by/4.0/), which permits unrestricted use, distribution, and reproduction in any medium, provided you give appropriate credit to the original author(s) and the source, provide a link to the Creative Commons license, and indicate if changes were made. 
an impressive flowering plant with about $15-45 \mathrm{~cm}$ in height, growing on large-stoned screes at the snow line, usually on glacier moraines in the mountain regions. To our knowledge, no previous studies have been reported neither on the phytochemical analysis of $P$. pulchrum nor on its biological activity. This is the first report on the chemical composition and antimicrobial activity of the essential oil from P. pulchrum growing in Mongolia.

\section{EXPERIMENTAL}

Plant material: Aerial parts of $P$. pulchrum were collected in the Mongolian Altai mountain region of Govi-Altai province, in July 2012. Plants were dried in shade at ambient temperature. Plant material was authenticated by Prof., ScD, Ch.Sanchir, Institute of General and Experimental Biology of the Mongolian Academy of Sciences.

Isolation of the essential oil: For essential oil extraction, 25 grams of milled plant material were extracted for $2 \mathrm{~h}$ in a Clevenger apparatus using hydrodistillation process.

Gas Chromatography-Mass Spectrometry (GC-MS) analysis: The oil was analyzed using a ThermoQuest Trace gas chromatography mass spectrometry system (TRACE 2000 series, Thermo Finnigan, Bremen, Germany) equipped with a ZB-5 capillary column (15 $\mathrm{m} \times 0.25 \mathrm{~mm}$, film thickness $0.25 \mu \mathrm{m}$, Pheno menex, Torrance, USA). The essential oil was diluted in $n$-hexane at a ratio of 1 to 10 . The samples were then injected and separated under programmed conditions to achieve complete separation of the essential oil. The oven temperature was kept at $40^{\circ} \mathrm{C}$ for 2 min and then ramped up to $280^{\circ} \mathrm{C}$ at $10^{\circ} \mathrm{C} \mathrm{min}{ }^{-1}$ followed by a heating to $320^{\circ} \mathrm{C}$ with a rate of $30^{\circ} \mathrm{C} \mathrm{min}{ }^{-1}$. The injector temperature was set to $220^{\circ} \mathrm{C}$ and helium served as carrier gas with a flow rate of $1.5 \mathrm{~mL} \mathrm{~min}^{-1}$ and a split ratio of 1:10. Mass spectra were recorded from 33-401 $\mathrm{Da}(\mathrm{m} / \mathrm{z})$ in full scan mode representing the total ion current chromatogram (TIC, Figure 1).

The relative composition of the essential oil was calculated based on GC peak area. Series of $C_{8}-C_{40}$ of $n$-alkanes were injected for the calculation of retention indices (RI) of individual components [16]. Proposals for the identity of the separated compounds were obtained by matching their recorded mass spectra and RIs with library mass spectra and RIs from NIST, Adams, and Massfinder databases [17-19].

Antimicrobial activity assay: $P$. pulchrum, essential oil antimicrobial activity was investigated against Gramnegative bacteria, Gram-positive bacteria and fungi in accordance with reports by Krieg et al. [20].

In essence: Bacillus subtilis (6633), Staphylococcus aureus (134/94 MRSA; 511), Escherichia coli (458), Enterococcus faecalis (1528, VRSA), Pseudomonas aeruginosa (SG137, K799/6) and Mycobacterium vaccae (10670) were cultivated on standard I nutrient agar (NA I) in Petri dishes at $37^{\circ} \mathrm{C}$. Antifungal bioassays were conducted on yeast morphology agar (YMA) at $37^{\circ} \mathrm{C}$ for $\mathrm{C}$. albicans and on malt agar (MA) at $30{ }^{\circ} \mathrm{C}$ against Sporobolomyces salmonicolor (549) and Penicillium notatum. After inoculation, a disc (9 $\mathrm{mm}$ in diameter) was removed from the center of the Petri dish and $50 \mu \mathrm{L}$ of the test solution was added to the cavity. After $18 \mathrm{~h}$ of incubation at the respective temperatures the inhibiting areola were measured. Ciprofloxacin (5 $\mu \mathrm{g} \cdot \mathrm{ml}^{-1}$ in deionized water) and amphotericin $\mathrm{B}\left(10 \mu \mathrm{g} \cdot \mathrm{ml}^{-1}\right.$ in $\left.\mathrm{DMSO} / \mathrm{MeOH} 1: 1\right)$ were used as reference compounds against bacterial and fungal strains, respectively.

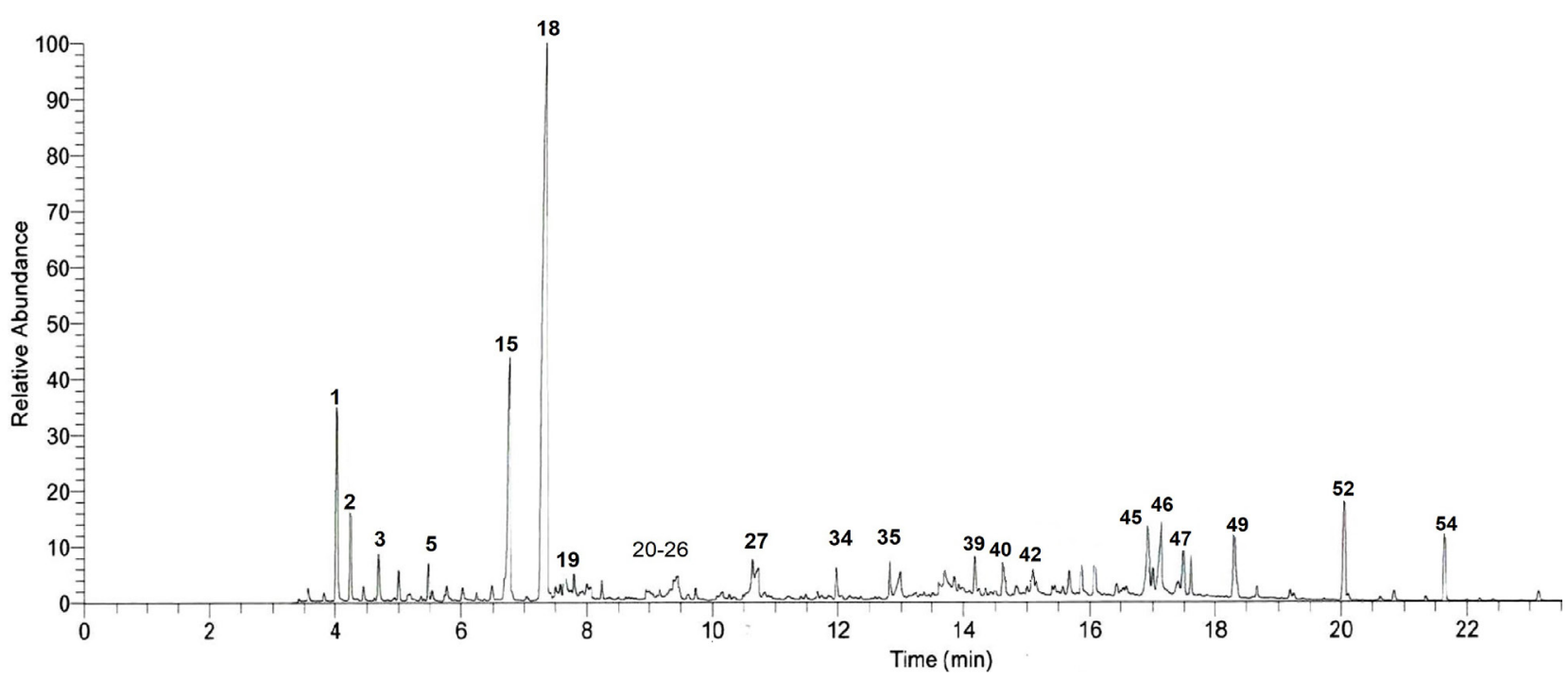

Fig. 1. Typical TIC-GC/MS chromatogram of $P$. pulchrum oil separated on a semi - polar ZB - 5 capillary column. Compounds are listed by their peak number in Table 1. 


\section{RESULTS AND DISCUSSION}

The yield of essential oil obtained by hydro-distillation from aerial parts of $P$. pulchrum was $0.1 \%$. The literature data indicate that the essential oil content in the genus Tanacetum ranges between $0.1 \%$ to $6.98 \%[5,12,21]$. Our result is close to those reported for $T$. audibertii (0.1\%) [11] and T. chilliophyllum (0.06-0.16\%) [22]. The general chemical profiling of the essential oils, the identity and percentage content of the individual components are summarized in Table 1. The GC-MS analyses of $P$. pulchrum essential oil provided the separation of 55 components, representing $99.7 \%$ of the oil. In particular, camphor (33.9\%), linalool (21.1\%), $\alpha$-pinene (9.0\%), (Z)- $\gamma$-curcumyl 2-methylbutyrate $(4.8 \%)$, pentylcurcume $(3.2 \%)$, camphene $(2.9 \%)$, tricosane $(2.8 \%)$ and nerolidol $(2.6 \%)$ were present as the main constituents.

Generally, essential oils are comprised of two or three major components in relatively high concentrations (20$95 \%$ ) and other components present in trace levels. On the other hand, quantity and quality of essential oil composition depended considerably on the type of variety, growth stage, time of collection and climatic conditions of the habitat. Table 2 shows a comparison between the major components of $P$. pulchrum essential oil and some species of Tanacetum. A comparison of the data presented in this paper with those in the literature for other species of Tanacetum shows that there are qualitative and quantitative differences in the levels of some of the compounds present. Our results indicate that the camphor, linalool and $\alpha$-pinene are three major compounds of $P$. pulchrum essential oil.

Table 1. Constituents of the essential oil from Pyrethrum pulchrum

\begin{tabular}{|c|c|c|c|c|}
\hline No & $\mathbf{R I}$ exp. & $\mathbf{R I}_{\mathrm{db}}$ & Compound & $\begin{array}{c}\text { RPA, } \\
\%\end{array}$ \\
\hline 1 & 928 & 932 & $\alpha$-Pinenez & 9.0 \\
\hline 2 & 942 & 946 & Camphene & 2.85 \\
\hline 3 & 971 & 974 & $\beta$-Pinene & 1.40 \\
\hline 4 & 990 & 981 & 2-Pentylfuran & 0.40 \\
\hline 5 & 1001 & 1002 & $\alpha$-Phellandrene & 1.03 \\
\hline 6 & 1003 & 1004 & 2-methyl-, 2-methylpropyl ester & 0.14 \\
\hline 7 & 1013 & 1014 & $\alpha$-Terpinene & 0.18 \\
\hline 8 & 1022 & 1020 & p-Cymene & 0.64 \\
\hline 9 & 1025 & 1025 & Limonene & 0.31 \\
\hline 10 & 1038 & 1032 & $(E)-\beta$-Ocimene & 0.27 \\
\hline 11 & 1044 & 1036 & Benzene acetaldehyde & 0.14 \\
\hline 12 & 1057 & 1054 & $\gamma$-Terpinene & 0.22 \\
\hline 13 & 1072 & 1067 & cis-Linalool oxide & 0.15 \\
\hline 14 & 1087 & 1084 & trans-Linalool oxide & 0.52 \\
\hline 15 & 1100 & 1095 & Linalool & 21.12 \\
\hline 16 & 1103 & 1100 & Methyl butyl-2-methyl butyrate-2 & 0.61 \\
\hline 17 & 1108 & 1103 & Methyl butyl isovalerate-2 & 0.19 \\
\hline 18 & 1139 & 1141 & Camphor & 33.94 \\
\hline 19 & 1162 & 1165 & Borneol & 0.67 \\
\hline 20 & 1175 & 1174 & Terpinen-4-ol & 0.43 \\
\hline 21 & 1190 & 1186 & $\alpha$-Terpineol & 0.18 \\
\hline 22 & 1235 & 1232 & Thymol, methyl ether & 0.05 \\
\hline 23 & 1243 & 1244 & Geranial & 0.06 \\
\hline 24 & 1295 & 1289 & Thymol & 0.16 \\
\hline 25 & 1317 & 1315 & $(2 \mathrm{E}, 4 \mathrm{E})$-Decadienal & 0.08 \\
\hline 26 & 1358 & 1356 & Eugenol & 0.01 \\
\hline 27 & 1375 & 1373 & $n$-Decanoic acid & 1.06 \\
\hline 28 & 1382 & 1379 & Geranyl acetate & 0.38 \\
\hline 29 & 1415 & 1421 & $(E)-\beta$-Caryophyllene & 0.08 \\
\hline
\end{tabular}

\begin{tabular}{|c|c|c|c|c|}
\hline No & $\mathbf{R I}_{\text {exp. }}$ & $\mathbf{R I}_{\mathrm{db}}$ & Compound & $\begin{array}{l}\text { RPA, } \\
\%\end{array}$ \\
\hline 30 & 1455 & 1454 & $(E)-\beta$-Farnesene & 0.24 \\
\hline 31 & 1467 & 1466 & Dehydrosesquicineol & 0.17 \\
\hline 32 & 1472 & 1474 & $\beta$-Chamigrene & 0.01 \\
\hline 33 & 1477 & 1484 & Germacrene D & 0.07 \\
\hline 34 & 1492 & 1494 & $\alpha$-Selinene & 1.80 \\
\hline 35 & 1563 & 1561 & (E)-Nerolidol & 2.63 \\
\hline 36 & 1579 & 1582 & Caryophyllene oxide & 0.25 \\
\hline 37 & 1623 & 1626 & Benzophenone & 0.06 \\
\hline 38 & 1634 & 1639 & allo-Aromadendrene epoxide & 0.10 \\
\hline 39 & 1683 & 1673 & $\alpha$-Bisabolol & 0.70 \\
\hline 40 & 1726 & 1730 & Chamazulene & 0.52 \\
\hline 41 & 1738 & 1742 & $(2 E, 6 E)$-Farnesol & 0.07 \\
\hline 42 & 1747 & 1741 & $\alpha$-Cyperone & 0.54 \\
\hline 43 & 1845 & 1844 & $\begin{array}{l}\text { 2-Pentadecanone, } \\
\text { 6,10,14-trimethyl }\end{array}$ & 0.86 \\
\hline 44 & 1926 & 1821 & Methyl hexadecanoate & 0.17 \\
\hline 45 & 1952 & 1951 & Pentylcurcumene & 3.21 \\
\hline 46 & 2010 & 2011 & (Z)- $\gamma$-Curcumyl 2-methylbutyrate & 4.82 \\
\hline 47 & 2024 & 1701 & Arglabin & 0.57 \\
\hline 48 & 2091 & 2095 & Methyl linoleate & 0.02 \\
\hline 49 & 2098 & 2100 & Heneicosane & 1.24 \\
\hline 50 & 2139 & 2132 & Linoleic acid & 0.78 \\
\hline 51 & 2199 & 2200 & Docosane & 0.08 \\
\hline 52 & 2299 & 2300 & Tricosane & 2.78 \\
\hline 53 & 2400 & 2400 & Tetracosane & 0.15 \\
\hline 54 & 2499 & 2500 & Pentacosane & 1.36 \\
\hline \multirow[t]{2}{*}{55} & 2699 & 2700 & Heptacosane & 0.20 \\
\hline & & & SUM & 99.67 \\
\hline
\end{tabular}

Retention indices (RI) measured on a ZB-5 column; exp: experimental values, db: values from databases; RPA: relative peak area. 
Table 2. Major components of essential oils from P. pulchrum and some species of Tanacetum

\begin{tabular}{|c|c|c|}
\hline Species & Major constituents & References \\
\hline P. pulchrum & camphor - 33.9\%, linalool - $21.1 \%$, $\alpha$-pinene - $9.0 \%$ & our result \\
\hline T. parthenium & camphor $-45.1 \%$, chrysanthenyl acetate $-21.5 \%$, camphene $-9.6 \%$ & [23] \\
\hline T. parthenium & camphor - $53.8 \%$, trans- $\beta$-farnesene $-8.3 \%$ & [24] \\
\hline T. punctatum & camphor $-45.5 \%$, trans- $\beta$-farnesene $-7.4 \%$ & [24] \\
\hline T. chiliophyllum & camphor $-32.5 \%, 1,8$-cineol $-16.1 \%$ & [14] \\
\hline T. armenum & camphor - $27 \%, 1,8$-cineol - $11 \%$ & [25] \\
\hline T. vulgare & camphor - 22.3-41.4\%, 1,8-cineol - 10.5-26.4\% & [26] \\
\hline T. pinnatum & camphor - $23.2 \%, \alpha$-penine $-8.5 \%$, camphene $-7.7 \%$ & [27] \\
\hline T. angulatum & 1,8-cineol - $75.3 \%$, camphor - $8.1 \%$ & [22] \\
\hline T. praeteritum & borneol - 28\%, 1,8-cineol - $12 \%$ & [3] \\
\hline T. audibertii & artemisia keton - $39.8 \%$, trans-linalool oxide $-32 \%$ & {$[11]$} \\
\hline T. messicyticu & thujone $-51 \%$ & [3] \\
\hline T. argyrophyllum & cis-thujone $-69.9 \%$ & [13] \\
\hline T. balsamita & carvone $-52 \%$ & [25] \\
\hline T. longifolium & eudesmol - $22.5 \%, 1,4$-dimethyl azulene - $13.5 \%$, germacrone - $8.2 \%$ & {$[28]$} \\
\hline
\end{tabular}

Table 3. Antimicrobial activity of essential oil from P. pulchrum

\begin{tabular}{lccc}
\hline \multirow{2}{*}{ Microorganism } & \multicolumn{3}{c}{ Inhibition zone (mm) } \\
\cline { 2 - 4 } & Essential oil & Ciprofloxacin & Amphotericin B \\
\hline Bacillus subtilis (6633) & 11 & 29 & - \\
Staphylococcus aureus (511) & 11 & 19 & - \\
Staphylococcus aureus (134/94, MRSA) & - & - & - \\
Enterococcus faecalis (1528, VRSA) & 14 & 16 & - \\
Escherichia coli (458) & 0 & $24 / 32$ & - \\
Pseudomonas aeruginosa (K977/61) & 17 & $28 / 35$ & - \\
\hline Pseudomonas aeruginosa (SG 137) & - & 25 & - \\
Mycobacterium vaccae (10670) & 19 & 22 & - \\
Sporidiobolus salmonicolor & - & - & 19 \\
Candida albicans & 12 & - & 20 \\
Penicillium notatum & - & - & 19 \\
\hline
\end{tabular}

One of the major constituents of the P. pulchrum is camphor. There are many pharmaceutical applications for camphor such as topical analgesic, antiseptic, antispasmodic, antipruritic, anti-inflammatory, antiinfective and cough suppressant [29]. Linalool, identified as the other major constituent in the essential oil of P.pulchrum, is a well-known sedative [30].

In addition, in the essential oil of $P$. pulchrum, compounds with an interesting biological activity, such as arglabin and chamazulene were detected with a relative amount of $0.57 \%$ and $0.52 \%$, respectively.

Arglabin belongs to the guaianolide, the class of sesquiterpene lactones, previously isolated from Artemisia species [31]. Arglabin shows a promising antitumor activity against different tumor cell lines [32]. Chamazulene is an aromatic sesquiterpene found in a variety of plants including chamomile (Matricaria chamomilla), wormwood (Artemisia absinthium) and yarrow (Achillea millefolium) [33]. Chamazulene has anti-inflammatory properties in vivo and inhibits the CYP1A2 enzyme involved in leukotriene biosynthesis [34].

During the last decades, antimicrobial plant products have gained special interest because of the resistance to antibiotics that some microorganisms have acquired, the increasing popular concern about the safety of food and the potential impact of synthetic additives on health. One of the novel ways to reduce the proliferation of microorganisms is the use of essential oils [35]. Thus, the antimicrobial activities of the essential oil of P.pulchrum were studied against eight bacterial and three fungi strains (Table 3).

Antimicrobial activity was detectable in six out of 11 cases (Bacillus subtilis, Staphylococcus aureus, 
Enterococcus faecalis, Pseudomonas aeruginosa, Mycobacterium vaccae and Candida albicans). The results of the antimicrobial tests of the essential oil from the aerial parts displayed an intermediate effect $[20,36]$ on the Gram-negative bacteria $P$. aeruginosa (K799/61) and M. vaccae (10670). On the other hand, the essential oil exhibited a weak activity against Grampositive bacteria, B. subtilis (6633), S. aureus (511) and E. faecalis (VRSA), and against the fungus $C$. albicans. No inhibition was observed against $S$. aureus 134/94 (MRSA), E. coli (458), P. aeruginosa (SG137) and the fungi $S$. salmonicolor and $P$. notatum.

Several studies have also reported that T. parthenium essential oils which are rich in camphor, prevent the growth of some bacteria such as $S$. aureus, $S$. epidermides, S. flexneri, Klebsialla pneumonia, $E$. coli (25923 and 157), methicillin resistant S. aureus, B. subtilis, S. saprophyticus and P. aeruginosa [23, $24,37]$. However, other publications reported that the essential oils of $T$. parthenium (from various regions) were resistant to E. coli, B. subtilis and S. aureus [5, 38].

As already mentioned, natural habitat of plant species was having a bigger impact on the chemical composition and even the biological activity of the essential oils.

\section{CONCLUSION}

In the current study, the chemical composition and antimicrobial activity of the essential oil of $P$. pulchrum from Mongolia was investigated for the first time. The yield of essential oil obtained by hydro-distillation from $P$. pulchrum was 0.1 percent of the dried weight. In total, 55 components were identified representing $99.7 \%$ of the oil. Camphor (33.9\%), linalool $(21.1 \%)$, $\alpha$-pinene (9.0\%), (Z)- $\gamma$-curcumyl-2-methylbutyrate $(4.8 \%)$, pentylcurcumene $(3.2 \%)$, camphene $(2.9 \%)$, tricosane $(2.8 \%)$, nerolidol $(2.6 \%)$, $\alpha$-selinene $(1.8 \%)$ and $\beta$-pinene $(1.4 \%)$ were the main components. The essential oil from $P$. pulchrum exhibited an intermediate antimicrobial effect on bacteria $P$. aeruginosa (K799/61) and $M$. vaccae (10670).

\section{REFERENCE}

1. The Plant List: Compositae. Royal botanic gardens kew and Missouri botanic garden. Retrieved 07 December 2018.

2. Brown A.M.G., Edwards C.M., Hartman T.P.V., Marshall J.A., et al. (1999) Sexual hybrids of Tanacetum: Biochemical, cytological and pharmacological characterization. J. Exp. Bot., 50(333), 435-444. doi:10.1093/jxb/50.333.435

3. Kumar V., Tyagi D. (2013) Chemical composition and biological activities of essential oils of genus Tanacetum - A review. J. Pharmacogn. Phytochem., 2(3), 159-163.

4. Rohloff J., Mordal R., Dragland S. (2004) Chemotypical variation of tansy (Tanacetum vulgare $L$.) from 40 different locations in Norway. J.
Agric. Food Chem., 52(6), 1742-1748. doi:10.1021/ if0352430

5. Izadi Z., Esna-Ashari M., Piri K., Davoodi P. (2010) Chemical composition and antimicrobial activity of feverfew (Tanacetum parthenium) essential oil. Int. J. Agric. Biol., 12(5), 759-763.

6. Esmaeili M.A., Sonboli A., Ayyari Noushabadi M. (2010) Antioxidant and protective properties of six Tanacetum species against hydrogen peroxideinduced oxidative stress in K562 cell line: A comparative study. Food Chem., 121(1), 148-155. doi:10.1016/j.foodchem.2009.12.022

7. Ernst E., Pittler M.H. (2000) The efficacy and safety of feverfew (Tanacetum parthenium L.): An update of a systematic review. Public Health Nutr., 3(4a), 509-514. doi:10.1017/S1368980000000598

8. Volodya Ts. (2014) Methods for the clinical usage of Mongolian Medicinal plants. Ulaanbaatar. ISBN: 978-99929-0-431-3 (in Mongolian)

9. Khaidav T., Menshikova T.L. (1978) Medicinal Plants in Mongolian Traditional Medicine. state publishing house, Ulaanbaatar (In Mongolian)

10. Abad M.J., Bermejo P., Villar A. (1995) An approach to the genus Tanacetum $L$. (Compositae): Phytochemical and pharmacological review. Phyther. Res., 9(2), 79-92. doi:10.1002/ ptr.2650090202

11. Maxia A., Sanna C., Piras A., Porcedda S., Falconieri D., et al. (2015) Chemical composition and biological activity of Tanacetum audibertii (Req.) DC. (Asteraceae), an endemic species of Sardinia Island, Italy. Ind. Crops Prod., 65, 472476. doi:10.1016/j.indcrop.2014.10.039

12. Mohsenzadeh F., Chehregani A., Amiri H. (2011) Chemical composition, antibacterial activity and cytotoxicity of essential oils of Tanacetum parthenium in different developmental stages. Pharm. Biol., 49(9), 920-926. doi:10.3109/138802 $\underline{09.2011 .556650}$

13. Akpulat H.A., Tepe B., Sokmen A., Daferera D., and Polissiou M. (2005) Composition of the essential oils of Tanacetum argyrophyllum (C. Koch) Tvzel. var. argyrophyllum and Tanacetum parthenium (L.) Schultz Bip. (Asteraceae) from Turkey. Biochem. Syst. Ecol., 33(5), 511-516. doi:10.1016/j. bse.2004.10.006

14. Mohammad bagher Rezaee, Kamkar Jaimand, M.N. (2013) Chemical composition of the essential oil of three Tanacetum species from North-West of Iran. J. Med. Plants By-products, 2(2012), 79-82.

15. Grubov V.I. (1982) Key to the Vascular Plants of Mongolia, Nauka, Leningrad.

16. Van den Dool H., Kratz P.D. (1963) A Generalization of retention index system including linear temperature programmed gas-liquid partition chromatography. J Chromatogr, 11(4), 463-71.

17. NIST. NIST/EPA/NIH Mass Spectral Library. Retention Index Library, 2014. 
18. Adams R.P. (2007) Identification of essential oil components by gas chromatography/mass spectromethry, 4th ed., Allured Pub Corp., USA. ISBN-13: 978-1932633214

19. Hochmuth D.H. (2010). MassFinder 4.21, Hochmuth Scientific Consulting, Hamburg, Germany.

20. Krieg R., Jortzik E., Goetz A. A., Blandin S., et al. (2017) Arylmethylamino steroids as antiparasitic agents. Nat. Commun., 8, 14478 doi:10.1038/ ncomms14478

21. Mirjalili M.H., Salehi P., Sonboli A., Mohammadi Vala M. (2007) Essential oil composition of feverfew (Tanacetum parthenium) in wild and cultivated populations from Iran. Chem. Nat. Compd., 43(2), 218-220.doi:10.1007/s10600-007-0085-2

22. Polatoĝlu K., Demirci B., Demirci F., Gören N., Can Başer K.H. (2012) Biological activity and essential oil composition of two new Tanacetum chiliophyllum (Fisch. \& Mey.) Schultz Bip. var. chiliophyllum chemotypes from Turkey. Ind. Crops Prod., 39, 97105. doi:10.1016/j.indcrop.2012.02.005

23. Izadi Z., Aghaalikhani M., Esna-Ashari M., Davoodi P. (2013) Determining chemical composition and antimicrobial activity of feverfew (Tanacetum parthenium L.) essential oil on some microbial strains. Zahedan J. Res. Med. Sci. J., 15(6), 8-13.

24. Shafaghat A., Ghorban-Dadras O., Mohammad hosseini M., Akhavan M., Shafaghatlonbar M., Panahi A. (2017) A comparative study on chemical composition and antimicrobial activity of essential oils from Tanacetum parthenium (L.) Schultz. Bip. and Tanacetum punctatum (Desr.) Grierson. Leaves from Iran. J. Essent. Oil Bearing Plants, 20(4), 1143-1150. doi:10.1080/0972060X.2017.1383859

25. Can Baser K.H., Demirci B., Tabanca N., Ozek T., Goren N. (2001) Composition of the essential oils of Tanacetum armenum (DC.) Schultz Bip., T. balsamita L., T. chiliophyllum (Fisch. \& Mey.) Schultz Bip. var. chiliophyllum and T. haradjani (Rech. fil.) Grierson and the enantiomeric distribution of camphor and carvone. Flavour Fragr. J., 16(3), 195-200. doi:10.1002/ffj. 977

26. Mockute, D., Judzentiene, A. (2004) Composition of the essential oils of Tanacetum vulgare L. growing wild in Vilnius district (Lithuania). J. Essent. Oil Res., 16(6), 550-553. doi:10.1080/10412905.2004 .9698795

27. Esmaeili A., Amiri H., Mmaterial P. (2011) The in vitro antioxidant and antibacterial activities of Tanacetum pinnatum boiss.grow in Iran. Bulg. Chem. Commun., 43(4), 532-537.
28. Kumar V., Sharma Y. (2016) Chemical composition and antibacterial activity of essential oils of Tanacetum longifolium. Int. J. Curr. Microbiol. Appl. Sci., 5(10), 836-841. doi:10.20546/ ijcmas.2016.510.091

29. Mihaylova H., Fakih H. (2013) Cherubism - A case report. Rentgenol. i Radiol., 52(3), 203-208.

30. Elisabetsky E. (2002) Chapter 11 Traditional medicines and the new paradigm of psychotropic drug action. Adv. Phytomedicine, 1(C), 133-144. doi:10.1016/S1572-557X(02)80020-4

31. Adekenov S.M., Mukhametzhanov M.N., Kagarlitskii A.D., Kupriyanov A.N. (1982) Arglabin - a new sesquiterpene lactone from Artemisia glabella. Chem. Nat. Compd., 18(5), 623-62.

32. Lone S.H., Bhat K.A., Khuroo M.A. (2015) Arglabin: From isolation to antitumor evaluation. Chem. Biol. Interact., 240, 180-198. doi:10.1016/j. cbi.2015.08.015

33. Conti B., Canale A., Bertoli A., Gozzini F., P.L. (2010) Essential oil composition and larvicidal activity of six Mediterranean aromatic plants against the mosquito Aedes albopictus (Diptera: Culicidae). Parasitol. Res., 107(6), 1455-61.

34. Safayhi H., Sabieraj J., Sailer E.R., Ammon H.P. (1994) Chamazulene: An antioxidant-type inhibitor of leukotriene B4 formation. Planta Medica., 60, 410-413.

35. Bagci E., Kursat M., Kocak A., Gur S. (2008) Composition and antimicrobial activity of the essential oils of Tanacetum balsamita L. subsp. balsamita and T. chiliophyllum (Fisch. et Mey.) Schultz Bip. var. chiliophyllum (Asteraceae) from Turkey. J. Essent. Oil Bearing Plants, 11(5), 476484. doi:10.1080/0972060X.2008.10643656

36. Bauer A.W., Kirby W.M.M., Sherris J.C., Turck K. (1966) Antibiotic Susceptibility test by a standardized single disk method. Am. J Clin. Pathol., 45, 493-496.

37. Polatoglu K., Demirci F., Demirci B., Gören N., Başer K.H.C. (2010) Antibacterial activity and the variation of Tanacetum parthenium (L.) Schultz Bip. essential oils from Turkey. J. Oleo Sci., 59(4), 177184. doi:10.5650/jos.59.177

38. Saharkhiz M.J., Satari Morteza., Goudarzi Gholam Reza., Omid Beygi. (2008). Assesment of antibacterial properties of Tanacetum Parthenium L. essential oil. Iran. J. Med. Aromat. Plants, 24(1), 47-55. 